\title{
PENGARUH PENERAPAN MODEL BLENDED LEARNING TERHADAP HASIL BELAJAR SISWA PADA MATA PELAJARAN AKUNTANSI \\ DI SMK NEGERI 11 BANDUNG
}

\author{
Ike Kiranawati
}

\begin{abstract}
ABSTRAK
Tujuan penelitian ini adalah untuk mengetahui pengaruh penerapan model blended learning terhadap hasil belajar siswa pada mata pelajaran akuntansi. Sampel penelitian adalah kelas XI Akuntansi 4 SMK Negeri 11 Bandung sebagai kelas eskperimen dan XI Akuntansi 3 sebagai kelas kontrol. Metode penelitian yang digunakan adalah metode Quasi Eksperimen dengan Postest-Only Control Design. Pengujian hipotesis dilakukan dengan menggunakan uji t. Hasil penelitian menunjukan gambaran penerapan model blended learning secara umum berlangsung efektif. Hasil pengujian hipotesis dengan menggunakan uji t menunjukan bahwa nilai $t$ hitung 11,455 dan nilai $t$ tabel dengan $\alpha \quad 0,05$ menunjukan nilai 1,998. Karena thitung $>t_{\text {tabel }}$ berarti bahwa terdapat perbedaan hasil belajar siswa kelas eksperimen yang menerapkan model blended learning dengan hasil belajar siswa kelas kontrol yang tidak menerapkan model blended learning pada mata pelajaran akuntansi. Dengan adanya perbedaan tersebut dapat disimpulkan bahwa penerapan model blended learning berpengaruh terhadap hasil belajar siswa pada mata pelajaran akuntansi.
\end{abstract}

Kata Kunci : Blended Learning, Hasil Belajar

\section{Pendahuluan}

Perkembangan tekonologi informasi dan komunikasi di Indonesia saat ini sudah semakin berkembang. Teknologi informasi dan komunikasi dapat memudahkan dalam pembelajaran, dan mendapatkan informasi yang dibutuhkan dari mana saja, kapan saja, dan dari siapa saja. Dalam dunia pendidikan perkembangan teknologi informasi mulai dirasa mempunyai dampak yang positif karena dengan berkembangnya teknologi informasi dunia pendidikan mulai memperlihatkan perubahan yang cukup signifikan. Seperti yang dikemukakan oleh Uno \& Lamatenggo (2010 : 60) bahwa "Teknologi dapat meningkatkan kualitas dan jangkauan apabila digunakan secara bijak untuk pendidikan dan latihan".

Saat ini banyak sekali ragam teknologi pembelajaran yang berkembang di masyarakat. Salah satu wadah yang dirasa paling berperan dalam dunia teknologi informasi dan komunikasi di Indonesia saat ini adalah internet. Sumber belajar dan informasi dapat diperoleh melalui kegiatan membaca buku, jurnal, tabloid, bulletin, maupun sumber belajar yang disediakan melalui internet, televisi, video cassette, video compact disk (VOID) ataupun melalui komputer. Oleh sebab itu sudah seharusnya teknologi pembelajaran dapat membuat kegiatan pembelajaran menjadi lebih luas, tidak sekedar 
interaksi guru dan siswa didalam ruang kelas dan waktu yang terbatas. Semua teknologi informasi dan komunikasi dalam dunia pendidikan saat ini sudah seharusnya menjadi indikator keberhasilan pendidikan.

Salah satu indikator keberhasilan pendidikan adalah tercapainya pendidikan yang efektif. Pendidikan yang efektif adalah suatu pendidikan yang memungkinkan peserta didik untuk dapat belajar dengan mudah, menyenangkan dan mencapai tujuan sesuai dengan yang diharapkan. Dengan demikian, pendidik dituntut untuk dapat meningkatkan keefektifan pembelajaran agar pembelajaran dapat bermanfaat. Keberhasilan pendidikan di sekolah dapat diukur dengan hasil belajar yang dicapai oleh siswa.

SMK Negeri 11 Bandung merupakan salah satu SMK yang berprestasi dalam bidang pendidikan maupun yang lainnya.Pada tahun 2012 lalu, SMK Negeri 11 Bandung memenangkan Juara Umum Lomba Cepat Tepat Akuntansi Pekan Akuntansi Raya tingkat SMK Sejabar-Banten.Pada 2013 pun SMK Negeri 11 kembali memenangkan Juara III Lomba Cepat Tepat Akuntansi Pekan Akuntansi Raya tingkat SMK Sejabar-Banten. Saat ini SMK Negeri 11 Bandung juga menjadi juara 1 regional Bandung di ajang yang sama di tahun 2014 ini.

Namun permasalahan yang muncul adalah tidak meratanya tingkat pemahaman dan hasil belajar siswa terutama dalam mata pelajaran akuntansi di SMK Negeri 11 Bandung.Hal tersebut dapat dilihat dari data hasil belajar siswa berikut ini :
Tabel 1

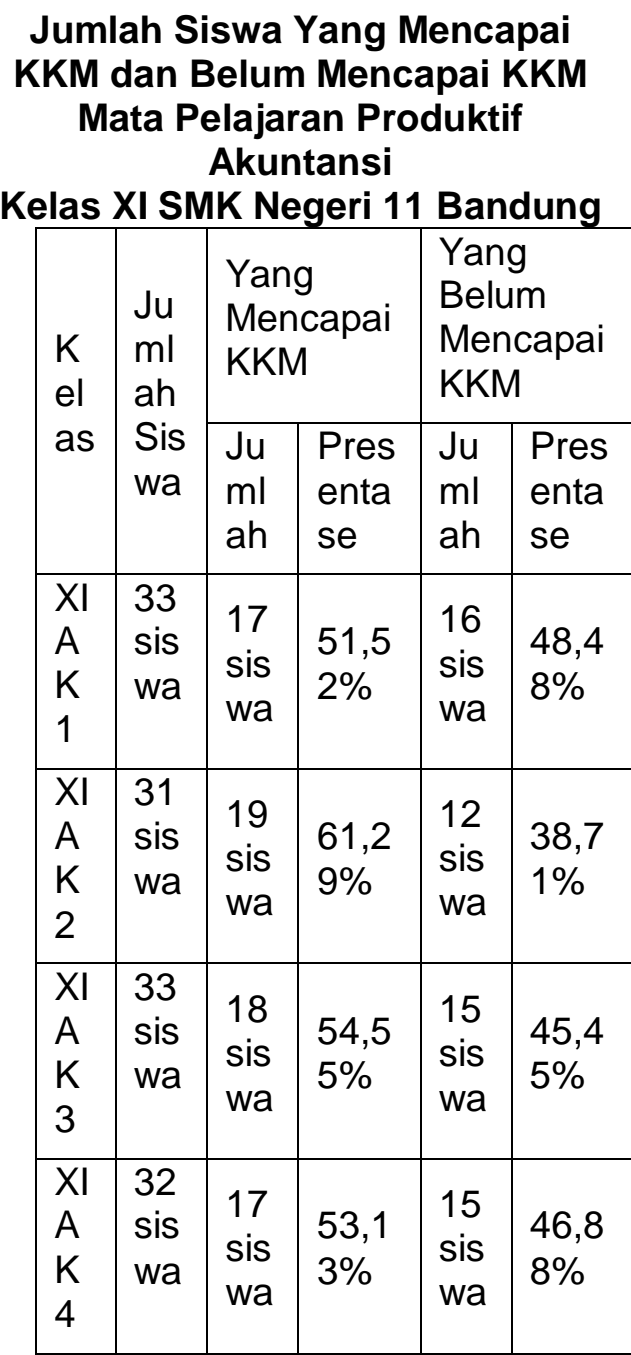

Sumber : Data SMKN 11 Bandung

Berdasarkan data pada tabel 1 terlihat bahwa siswa yang nilainya belum mencapai KKM setiap kelasnya hampir mencapai $50 \%$. Hasil belajar yang rendah dapat mempengaruhi efektifitas pembelajaran yang selanjutnya, sehingga materi pembelajaran akan semakin sulit diterima oleh siswa yang memiliki hasil belajar yang rendah. Siswa dituntut untuk memahami setiap submateri agar siswa dapat melanjutkan materi berikutnya dengan lancar. Ketika ada salah seorang siswa yang memiliki hasil belajar rendah 
dibiarkan untuk melanjutkan materi ajar tanpa pemahaman yang mendalam maka akan sulit pula bagi guru dalam menjelaskan materi ajar kepada siswa yang lainnya. Jika fenomena diatas dibiarkan, maka ini dapat berdampak pada menurunnya kualitas pembelajaran dan mutu pendidikan. Seperti yang telah dikemukakan sebelumnya bahwa hasil belajar merupakan faktor penting dalam pencapaian tujuan pendidikan. Rendahnya hasil belajar merupakan permasalahan yang harus diperhatikan karena jika hasil belajar rendah, kemungkinan besar tujuan pendidikan tidak akan tercapai secara optimal dan maksimal.

Siswa yang memiliki tingkat intelektual yang tinggi seringkali dapat menyerap materi ajar dengan cepat dan tepat, namun ada beberapa siswa yang masih sulit untuk menyerap materi pelajaran. Materi pelajaran akuntansi sebagian besar merupakan materi yang bersifat prosedural. Siswa harus memahami materi dasar untuk melanjutkan materi ke tahap berikutnya. Masih banyak siswa yang memerlukan waktu yang lebih lama untuk menyerap materi yang diajarkan oleh guru. Sumber belajar yang terbatas juga membatasi siswa dalam mempelajari kembali materi yang telah siswa dapatkan di sekolah. Selain itu, model pembelajaran yang digunakan oleh guru dalam proses belajar mengajar terkadang masih menggunakan model pembelajaran yang kurang berinovasi.

Penelitian ini bertujuan untuk mengetahui apakah terdapat perbedaan hasil belajar siswa kelas eksperimen yang menerapkan model pembelajaran blended learning dengan hasil belajar siswa kelas kontrol yang tidak menerapkan model blended learning dalam mata pelajaran akuntansi

\section{Landasan Teori}

Tinggi dan rendahnya hasil belajar yang diperoleh siswa dipengaruhi banyak faktor. Menurut Slameto (2010: 54-72) "Faktor-faktor yang mempengaruhi prestasi belajar banyak jenisnya, tetapi dapat digolongkan menjadi dua, yaitu faktor internal dan faktor eksternal". Sedangkan Syah (2006: 144) mengemukakan, bahwa :

Selain faktor eksternal dan faktor internal ada satu faktor lagi yang mempengaruhi hasil belajar yaitu faktor pendekatan belajar (approach to learning), yakni jenis upaya belajar siswa yang meliputi strategi dan metode yang digunakan siswa untuk melakukan

kegiatan pembelajaran materi -materi pelajaran.

Salah satu faktor yang mempengaruhi hasil belajar siswa adalah guru. Guru merupakan faktor penting dalam upaya pencapaian hasil belajar siswa. Peranan guru dalam mengelola proses belajar mengajar merupakan faktor yang mempengaruhi apakah keberhasilan belajar siswa dapat tercapai. Di era reformasi saat ini guru dituntut untuk lebih kreatif dan inovatif dalam menyampaikan materi sehingga mempermudah siswa dalam memahaminya. Salah satu kemampuan yang harus dimiliki seorang guru adalah kemampuan menerapkan model pembelajaran yang tepat demi tercapainya tujuan pembelajaran. Guru diharapkan mampu memberikan pembelajaran yang tepat bagi siswa terutama 
dalam menggunakan model pembelajaran.

Menurut hasil wawancara dengan salah satu guru mata pelajaran produktif akuntansi di SMK Negeri 11 Bandung, pembelajaran yang berjalan disana masih menggunakan metode pembelajaran ceramah. Sumber belajarnya pun masih terbatas. Tersedianya fasilitas-fasilitas yang diberikan oleh pihak sekolah ternyata tidak banyak mempengaruhi hasil belajar siswa. Fasilitas internet sekolah juga terkadang kurang dimanfaatkan siswa atau guru dalam mencari sumber belajar tambahan.

Saat ini banyak model pembelajaran yang diterapkan oleh guru dalam upaya mencapai keberhasilan belajar siswa. Model pembelajaran yang populer dilakukan adalah pembelajaran berbasis kelas (klasikal) dengan menggunakan metode ceramah. Namun dalam pembelajaran klasikal, proses belajar siswa terikat oleh dimensi ruang dan waktu. Selain itu, siswa menjadi cepat bosan dan menjadi pasif dalam memilih sumber belajar tambahan di luar sumber belajar yang diberikan oleh guru. Peran guru adalah menciptakan suasana pembelajaran yang kondusif, kreatif, menciptakan berbagai kiat dan model penyampaian materi pembelajaran serta membuat suasana pembelajaran menjadi menarik. Sebagaimana yang telah dikemukakan Syah (2011:123) bahwa "Pendekatan belajar (approach to learn) dan strategi atau kiat melaksanakan pendekatan serta metode belajar termasuk faktorfaktor yang turut menentukan tingkat keberhasilan belajar siswa". Pemilihan model pembelajaran haruslah sesuai dengan tujuan pembelajaran. Salah satu model yang dapat meningkatkan keberhasilan belajar siswa diantaranya adalah model Blended Learning.

Blended learning merupakan suatu model pembelajaran yang saat ini sedang marak digunakan dalam pendidikan. Blended learning merupakan model pembelajaran yang mengintegrasikan pembelajaran tatap muka dan pembelajaran jarak jauh yang menggunakan sumber belajar online maupun offline dan beragam pilihan komunikasi yang dapat digunakan oleh guru dan siswa. Seperti yang diungkapkan oleh New South Wales Department of Education and Training dalam jurnal yang ditulis oleh Sukarno (2012 : 3) bahwa : 'Provides a simple definition: Blended learning is learning which combines online and face-to-face approache'. Sasaran blended learning adalah menyediakan pengalaman pembelajaran yang paling efisien dan efektif dengan kombinasi metode pembelajaran.

Teori belajar yang mendasari pembelajaran blended learning adalah teori belajar kontruktivisme. Konsep teori belajar kontruktivisme yang menuntun siswa untuk membangun pengetahuannya dari pengalaman belajar sendiri dilihat sebagai proses aktif. Siswa diberi kesempatan melakukan aktivitas untuk menerapkan pengelolaan dan pemahaman informasi serta konsep materi pembelajaran secara lebih terintegrasi. Selain itu blended learning juga mengadopsi penerapan teori belajar behaviorisme dimana didalam blended learning siswa diharapkan dapat meningkatkan kemampuan pembelajarannya melalui latihan latihan dengan umpan balik yang cepat. Ketika siswa diberikan umpan balik oleh guru, maka akan timbul 
motivasi belajar siswa. Hal ini tidak terlepas dari teori kognitivisme bahwa pada dasarnya belajar merupakan proses internal yang melibatkan memori, motivasi, refleksi dan berfikir.

Pembelajaran tatap muka dan aktivitas belajar online, video, multimedia dan sarana telekomunikasi sangat menunjang proses pembelajaran. Pendidikan jarak jauh sekarang disajikan dalam dua cara yaitu synchronous mode di mana peserta menggunakan teknologi informasi dan komunikasi untuk berkomunikasi pada waktu yang bersamaan dan asynchronous mode di mana para peserta belajar atau berkomunikasi secara mandiri pada waktu yang berbeda kapan saja mereka online (anytimeanywhere learning) maupun offline. Dalam kenyataannya pertemuan tatap muka atau interaksi (synchronous) masih diperlukan untuk menunjang belajar mandiri dan asynchronous agar belajar dapat lebih efektif. Teknologi informasi dan komunikasi memfasilitasi interaksi antara siswa, guru, dan materi pembelajaran berbasis komputer. Komunikasi dapat dinamis dan bervariasi sesuai keinginan siswa dan guru, dan dapat terjadi dalam berbagai bentuk seperti e-mail, mailing list, chat, bulletin board, and konferensi komputer.

Materi akuntansi merupakan materi yang bersifat konsep dan prosedural. Dalam mempelajari akuntansi, siswa dituntut untuk mengerjakan banyak latihan agar terbiasa dengan kasus-kasus akuntansi. Menurut wawancara yang dilakukan peneliti kepada salah satu guru akuntansi di SMKN 11 Bandung, materi mengelola jurnal khusus sebagai materi akuntansi utama yang memerlukan tingkat pemahaman yang tinggi kadang sulit untuk dimengerti oleh siswa. Hal ini terjadi karena terbatasnya waktu untuk mengerjakan latihan-latihan dengan bimbingan guru di sekolah, padahal materi ini merupakan materi inti dari pembelajaran produktif akuntansi yang nantinya materi ini akan di ujikan dalam uji kompetensi nasional. Dalam mempelajari materi jurnal khusus, penerapan blended learning dapat membantu siswa dalam memperdalam konsep jurnal khusus dengan penambahan materi yang didapatkan siswa dari berbagai sumber belajar. Dengan model blended learning, siswa juga dapat melihat contoh-contoh transaksi yang terdapat dalam video-video pembelajaran yang tersedia dari internet, tidak hanya dari buku pelajaran. Materi jurnal khusus yang memerlukan banyak latihan dapat diatasi dengan penggunaan media social untuk proses latihan dengan bimbingan guru mata pelajaran diluar pembelajaran dikelas karena keterbatasan pertemuan di dalam kelas, membuat interaksi siswa dalam pembelajaran juga menjadi terbatas. Namun dengan model blended learning, siswa diharapkan dapat berinteraksi dengan guru maupun teman sekelasnya dalam ruang lain yaitu menggunakan sumber belajar online maupun offline dan beragam pilihan komunikasi. Sehingga siswa bisa lebih banyak mengerjakan latihan serta berkomunikasi dengan siswa lain untuk meningkatkan hasil belajar. Sejalan dengan karakteristik pembelajaran akuntansi yaitu belajar informasi, belajar konsep dan belajar keterampilan, blended learning memadukan potensi pertemuan tatap muka dikelas dan pembelajaran online yang memberikan kesempatan kepada siswa dalam memahami konsep dan 
informasi akuntansi serta membantu siswa dalam melatih keterampilan akuntansi.

Pergeseran paradigma pendidikan dari teacher center ke student center membuat siswa berfungsi sebagai subjek dalam pembelajaran dan guru merupakan fasilitator yang membimbing dan mengarahkan para siswanya agar dapat menemukan pemecahan terhadap suatu permasalahan dalam proses pembelajaran. Dengan demikian siswa tidak hanya tergantung pada guru saja. Ada banyak media yang bisa siswa gunakan untuk menunjang proses pembelajarannya. Selain itu siswa juga dapat bertukar informasi baik dengan guru maupun sesama temannya. Dengan demikian diharapkan dengan blended learning kualitas pembelajaran dapat ditingkatkan sehingga penguasaan materi juga meningkat.

\section{Metode Penelitian}

Metode yang digunakan dalam penelitian ini adalah metode eksperimen.Metode eksperimen ditujukan untuk meneliti hubungan sebab-akibat dengan memanipulasikan satu atau lebih variabel pada satu (atau lebih) kelompok eksperimental dengan membandingkan hasilnya dengan kelompok control yang tidak mengalami manipulasi. Manipulasi berarti merubah secara sistematis sifat-sifat (nilai-nilai) variabel bebas.Setelah dimanipulasikan, variabel bebas itu biasanya disebut treatment.Desain yang digunakan adalah desain Quasy Eksperimen dengan menggunakan Postest-Only Control Design. Desain ini dapat dituangkan kedalam skema sebagai berikut :

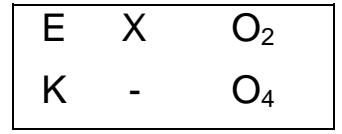

\section{Gambar 1 \\ Desain Penelitian}

(Sugiyono 2012 : 85)

Desain ini dilakukan dengan satu macam perlakuan, yakni penerapan model blended learning. Pada kelas eksperimen diberikan perlakuan $(\mathrm{X})$ yaitu model blended learning dan pada kelas kontrol tidak diberikan perlakuan (-). Kemudian setelah selesai perlakuan, kedua kelas diberikan posstest untuk mengetahui kondisi kelas setelah diberikan perlakuan. Setelah itu menguji perbedaan antara hasil posstest pada masing masing kelas.

\section{a. Teknik Pengumpulan data}

Dalam penelitian ini, teknik pengumpulan data yang dilakukan untuk mengetahui hasil belajar siswa adalah melalui tes. Tes yang digunakan pada penelitian ini adalah tes dengan bentuk soal uraian dengan jumlah 20 item soal. Postest dilakukan pada akhir penelitian yang bertujuan untuk mengetahui kondisi dan kemampuan siswa setelah diberi perlakuan penerapan model blended learning dibandingkan dengan siswa yang tidak diberi perlakuan penerapan model blended learning.

Dan peneliti juga melakukan observasi untuk melihat gambaran pelaksanaan model blended learning. Observasi yang dilaksanakan untuk mengukur gambaran pelaksanaan model blended learning adalah melalui angket dan lembar observasi eksperimen.

Angket yang digunakan untuk melihat efektivitas penerapan model blended learning adalah angket yang diadaptasi dari penelitian yang dilakukan oleh Akkoyunlu dan Soylu 
pada tahun 2008 yang berjudul Development of a Scale On Learners' Views On Blended Learning And Its Implementation Process. Terdapat enam indikator utama dalam penilaian pelaksanaan blended learning yaitu penilaian dalam pelaksanaan Live Event (pembelajaran tatap muka), Self Paced Learning (pembelajaran mandiri dengan media online dan offline), Performance Support Materials, Collaboration, Assesment dan penilaian umum.

\section{b. Teknik Analisis Data}

Analisis Data yang digunakan adalah dengan analisis butir soal tes serta analisis mengenai tingkat validitas dan reliabilitas soal tes. Sedangkan analisis deskriptif bertujuan untuk memperoleh gambaran mengenai efektifitas pembelajaran menggunakan model blended learning pada kelas XI Akuntansi 4 SMK Negeri 11 Bandung tahun ajaran 2014/2015. Adapun langkah dalam proses analisisnya adalah sebagai berikut.

1. Mentabulasi jawaban responden ke dalam format berikut:

2. Menentukan kriteria penilaian

3. Menentukan distribusi frekuensi, untuk mengetahui gambaran umum efektivitas penerapan model blended learning.

4. Menginterpretasikan hasil distribusi frekuensi untuk mengetahui gambaran baik secara keseluruhan maupun untuk setiap indikator.

Selanjutnya

hipotesis dilakukan untuk mengetahui apakah hipotesis diterima atau ditolak, sebelum melakukan pengujian hipotesis maka dilakukan terlebih dahulu pengujian normalitas data, homogenitas data lalu baru dilakukan pengujian hipotesis menggunakan uji t.

\section{Hasil dan Pembahasan}

Pada penelitian ini, model blended learning diterapkan pada kelas eksperimen yaitu kelas XI Akuntansi 4 selama 3 kali pertemuan pembelajaran. Setelah model blended learning diterapkan, maka dilakukan postes untuk mengukur hasil belajar siswa. Dan untuk melihat apakah model blended learing membantu siswa dalam meningkatkan hasil belajarnya, maka guru membandingkan hasil belajar kelas eksperimen tersebut dengan hasil belajar kelas kontrol atau kelas yang tidak menerapkan model blended learning.

Langkah awal adalah uji homogenitas untuk melihat apakah kedua kelas memiliki data yang homogen agar bisa dibandingkan atau sebaliknya memiliki data yang heterogen sehingga tidak bisa dibandingkan. Dan setelah dilakukan uji varians, didapatkan bahwa $F_{\text {hitung }} 1,1035<F_{\text {tabel }} 1,1814$ dan kedua kelas dinyatakan homogen, maka guru memberikan soal postes yang sama untuk membandingkan apakah terdapat perbedaan hasil belajar pada kelas eksperimen dengan hasil pembelajaran pada kelas kontrol.

Sebelum dilakukan uji
hipotesis, peneliti melakukan uji
normalitas dari data hasil postes
kelas kontrol dan eksperimen, dan
didapatkan bahwa keduanya
memiliki data yang berdistribusi
normal sehingga data dapat dilihat
terdapat perbedaan atau tidak
melalui uji statistika parametrik.


Setelah dilakukan pengujian data menggunakan uji t, didapatkan bahwa $t_{\text {hitung }} 11,455>$ nilai $t_{\text {tabel }}$ 1,998 sehingga $H_{0}$ ditolak dan $H_{1}$ diterima. Dengan demikian berarti bahwa terdapat perbedaan hasil belajar siswa kelas eksperimen yang menerapkan model pembelajaran blended learning dengan hasil belajar siswa kelas kontrol yang tidak menerapkan model pembelajaran blended learning.

Berdasarkan pengolahan data, rata-rata nilai postest kelas eksperimen adalah 92,72. Sedangkan, pada kelas kontrol ratarata nilai postest nya adalah 77,27 . Artinya, terdapat perbedaan ratarata yang signifikan antara kelas eksperimen dan kelas kontrol. Jumlah siswa yang sudah mencapai KKM pada kelas eksperimen adalah sebanyak 31 orang siswa sehingga persentase ketuntasannya adalah sebesar $96,87 \%$. Sedangkan jumlah siswa yang sudah mencapai KKM pada kelas kontrol adalah sebanyak 26 siswa sehingga persentase ketuntasannya sebesar $78,79 \%$. Adanya perbedaan hasil belajar pada kedua kelas tersebut menunjukkan bahwa model blended learning yang diterapkan pada kelas eksperimen berpengaruh positif terhadap hasil belajar siswa pada mata pelajaran akuntansi, khususnya pada materi mengelola jurnal khusus pada perusahaan dagang. Berikut ini adalah perolehan nilai siswa kelas eksperimen dan kelas kontrol :

Tabel 2

Perolehan Nilai Siswa

\begin{tabular}{|l|l|l|}
\hline \multirow{2}{*}{ Nilai } & \multicolumn{2}{|l|}{ Frekuensi } \\
\cline { 2 - 3 } & $\begin{array}{l}\text { Kelas } \\
\text { Kontrol }\end{array}$ & $\begin{array}{l}\text { Kelas } \\
\text { Eksperim } \\
\text { en }\end{array}$ \\
\hline $61-70$ & 3 & 0 \\
\hline
\end{tabular}

\begin{tabular}{|c|c|c|}
\hline $71-80$ & 22 & 2 \\
\hline $81-90$ & 8 & 8 \\
\hline $91-100$ & 0 & 22 \\
\hline Jumlah & 33 & 32 \\
\hline $\begin{array}{l}\text { Rata- } \\
\text { rata }\end{array}$ & 77,27 & 92,72 \\
\hline
\end{tabular}

Dilihat dari tabel 4.22 hasil belajar siswa kelas kontrol dan kelas eksperimen berbeda, hal ini terlihat dari perbedaan nilai rata-rata dari kedua kelas tersebut dan kelas eksperimen lebih unggul dibandingkan dengan kelas kontrol. $\mathrm{Hal}$ ini disebabkan karena terdapat perbedaan model pembelajaran yang diterapkan kepada kedua kelas tersebut.

Pada kelas kontrol yang tidak menerapkan model blended learning guru memberikan penjelasan materi hanya pada saat jam pembelajaran dikelas saja. Guru memberikan materi pembelajaran dengan menggunakan metode ceramah. Pembelajaran berlangsung satu arah. Sehingga menyebabkan beberapa siswa masih belum memahami materi tersebut. Materi mengenai jurnal khusus merupakan materi inti jurusan akuntansi yang nantinya akan dijadikan bahan uji kompetensi nasional, maka siswa dituntut untuk memiliki tingkat pemahaman yang tinggi mengenai materi ini. Sedangkan jam pelajaran yang disediakan hanya 6 jam pelajaran dikelas tiap minggunya. Siswa yang masih belum memahami penjelasan materi di dalam kelas memiliki keterbatasan waktu pembelajaran yang hanya 2 pertemuan saja tiap minggunya.

Berbeda dengan siswa kelas eksperimen yang menerapkan model blended learning dimana 
siswa yang masih belum memahami penjelasan materi di dalam kelas masih bisa berinteraksi dengan guru melalui kelas virtual (pembelajaran online). Dengan penerapan model blended learning siswa memiliki waktu yang lebih banyak untuk berinteraksi dengan guru. Sehingga siswa yang masih belum memahami materi pembelajaran dikelas dapat berkonsultasi lebih lanjut dengan guru. Dalam pembelajaran dikelas, guru dapat menjelaskan materi kepada siswa dengan berbagai metode pembelajaran dan siswa dapat menanyakan secara langsung materi pembelajaran yang belum dipahaminya. Selain itu, siswa juga dapat mengerjakan soal-soal latihan diluar jam pelajaran didalam kelas. Materi pembelajaran akuntansi terutama dalam materi jurnal khusus perusahaan dagang membutuhkan banyak latihan dalam memahami konsep dari materi tersebut. Sehingga semakin banyak siswa mengerjakan latihan, maka akan semakin mudah untuk memahami materi yang disampaikan. Jam pelajaran dikelas yang hanya 6 jam pelajaran per minggunya, dengan penerapan model blended learning siswa memiliki jam pelajaran tambahan melalui pembelajaran online. Dalam pembelajaran online siswa diberikan materi tambahan melalui ebook yang dibagikan melalui media sosial, video pembelajaran, serta artikel yang direkomendasikan guru untuk dipelajari oleh siswa. Pada saat pembelajaran dikelaspun siswa diberikan penjelasan kembali mengenai materi yang belum tuntas dibahas pada pembelajaran online. Sehingga pemahaman siswa dapat diperkuat dengan adanya penjelasan materi dan soal-soal latihan yang diberikan oleh guru.
Perbedaan

model

pembelajaran yang berbeda pada kelas yang berbeda memiliki pengaruh terhadap hasil belajar siswa. Dapat dilihat bahwa kelas yang menerapkan model blended learning memiliki hasil belajar yang cukup tinggi dibandingkan dengan kelas yang menerapkan pembelajaran face to face saja. Hal ini sejalan dengan pengungkapan Aunurrahman (2013 : 143) yang menegaskan bahwa penggunaan model pembelajaran yang tepat dapat mendorong tumbuhnya rasa senang siswa terhadap pelajaran, menumbuhkan dan meningkatkan motivasi dalam mengerjakan tugas, memberikan kemudahan bagi siswa untuk memahami pelajaran sehingga memungkinkansiswa mencapai hasil belajar yang lebih baik.

Dengan demikian dapat dikatakan bahwa penerapan model blended learning memiliki pengaruh yang positif terhadap hasil belajar siswa. Sehingga model ini efektif jika diterapkan pada mata pelajaran akuntansi perusahaan dagang, khususnya pada kompetensi dasar mencatat transaksi pada jurnal khusus. Tetapi peneliti tidak bisa membuat kesimpulan bahwa model blended learning ini efektif untuk semua kompetensi inti dalam mata pelajaran akuntansi. Penerapan model ini harus melihat karakteristik materi yang akan disampaikan, apakah materi tersebut memerlukan intensitas latihan yang sering atau hanya sekedar pemahaman teori dan konsep saja.

Hal ini sesuai dengan pengungkapan Faizal (dalam Husamah, 2014 : 34) bahwa 'Implementasi blended learning dapat mengingkatkan hasil belajar peserta didik'. Penelitian yang dilakukan sebelumnya juga mengatakan bahwa model blended 
learning dapat meningkatkan hasil belajar siswa. Penelitian yang dilakukan Syarif Izuddin tahun 2012 yang berjudul "Pengaruh Penerapan Model Blended Learning Terhadap Motivasi Dan Prestasi Belajar Siswa SMKN 1 Paringin" menunjukan bahwa terdapat perbedaan yang signifikan antara prestasi belajar siswa yang menggunakan model blended learning dan siswa yang menggunakan model face-to-face learning serta terdapat peningkatan prestasi belajar yang signifikan akibat adanya penerapan model blended learning. Begitupula dengan penelitian yang dilakukan oleh Akkoyunlu, B., \& Soylu, MY tahun 2008 yang berjudul "A Study of Student's Perceptions in a Blended Learning Environment Based on Different Learning Styles" menunjukkan bahwa hasil belajar siswa dapat meningkat dengan tidak menghilangkan proses tatap muka dikelas.

Dari hasil pengamatan yang dilakukan selama eksperimen, menunjukkan bahwa pelaksanaan model blended learning sejalan dengan pendapat Kusni (dalam Husamah, 2014 : 37) yang mengungkapkan bahwa :

1. Pengajar perlu memiliki keterampulan dalam menyelenggarakan $\quad e$ learning

2. Pengajar perlu menyiapkan referensi digital yang dapat menjadi acuan bagi peserta didik

3. Pengajar perlu merancang referensi yang sesuai atau terintegrasi dengan tatap muka

4. Pengajar perlu menyiapkan waktu untuk mengelola pembelajaran berbasis internet, misalnya untuk mengembangkan materi, mengembangkan instrumen asesmen dan menjawab berbagai pertanyaan yang diajukan peserta didik.

Dan dari hasil pengamatan, model blended learning dapat diterapkan dengan memperhatikan hal-hal berikut:

1. Pemahaman dan kesiapan guru dalam melaksanakan tahap demi tahap sesuai dengan aturan pada penerapan model blended learning

2. Pemahaman dan kesiapan siswa untuk melaksanakan kegiatan pembelajaran. Pemahaman dan kesiapan terhadap setiap tahap tahap kegiatan pembelajaran dengan model blended learning sangat penting agar kegiatan pembelajaran berlangsung dengan lancar dan tujuan pembelajaran dapat tercapai

3. Tersedianya waktu yang cukup untuk melaksanakan langkah-langkah model blended learning. Terutama dalam penjadwalan pembelajaran online yang harus disesuaikan dengan kemampuan siswa dan juga guru

4. Ketersediaan fasilitas dan bahan ajar yang dibutuhkan pada saat menerapkan model blended learning. Contohnya: tersedianya fasilitas internet yang memadai sehingga semua siswa dapat mengakses sumber belajar online.

Sehingga dengan terpenuhinya hal-hal di atas, pelaksanaan model blended learning dapat berjalan secara efektif dan 
membantu siswa dalam mencapai tujuan pembelajaran dan hasil pembelajaran yang optimal.

\section{Kesimpulan dan Saran}

\section{Kesimpulan}

Berdasarkan hasil penelitian yang telah dilakukan di SMK Negeri 11 Bandung, maka dapat disimpulkan bahwa:

1. Penerapan model blended learning berlangsung efektif pada kelas eksperimen yaitu kelas XI Akuntansi 4. Pada pertemuan pertama siswa mengikuti pembelajaran dikelas, mengirim tugas menggunakan email, dan diperkenalkan dengan media sosial edmodo. Pada pertemuan kedua guru memberikan sumber belajar tambahan seperti ebook, artikel dan video pembelajaran kepada siswa untuk menunjang proses pembelajaran. Dan pada pertemuan ketiga guru memberikan review materi yang telah disampaikan dan siswa mengerjakan latihanlatihan soal. Dalam pelaksanaan blended learning tidak terlepas dari berbagai hambatan diantara lain adalah masih kurangnya sosialisasi kepada siswa tentang penggunaan media sosial, kurangnya waktu pembelajaran dan keterbatasan siswa untuk mengakses internet. Namun secara keseluruhan pelaksanaan blended learning telah berlangsung dengan cukup baik. Hal ini $\begin{array}{lrr}\begin{array}{l}\text { ditunjukan dengan } \\ \text { penyebaran }\end{array} & \begin{array}{r}\text { hasil } \\ \text { angket }\end{array} \\ \text { observasi, } & 50 \% & \begin{array}{r}\text { siswa } \\ \text { bahwa }\end{array}\end{array}$ efektivitas penerapan model blended learning secara umum berada pada kategori sedang. Efektivitas penerapan Live Event, Collaboration, Performance Support Materials dan Assesment berada pada kategori sedang sedangkan efektivitas penerapan SelfPaced Learning berada pada kategori rendah.

2. Terdapat perbedaan hasil belajar siswa kelas XI Akuntansi 4 yang menerapkan model pembelajaran blended learning dengan hasil belajar siswa kelas XI Akuntansi 3 yang tidak menerapkan model blended learning

\section{Saran}

Hasil penelitian menunjukan bahwa penerapan model blended learning secara umum telah berlangsung efektif, dan terdapat perbedaan hasil belajar siswa yang menerapkan model pembelajaran blended learning dengan hasil belajar siswa yang tidak menerapkan model blended learning namun penerapan model blended learning ini masih memerlukan evaluasi lebih lanjut agar bisa diterapkan secara efektif tidak hanya pada program keahlian akuntansi, tetapi pada program keahlian lain. Untuk tercapainya peningkatan efektivitas penerapan model blended learning perlu adanya partisipasi dari berbagai pihak terkait.

\section{Daftar Pustaka}


Arikunto, S. (2011). Dasar-Dasar Evaluasi Pembelajaran.Jakarta : Bumi Aksara . (2006). Prosedur Penelitian Suatu Pendekatan Praktik. Jakarta. : Rineka cipta

Arifin, Z. (2011). Penelitian Pendidikan : Metode \& Paradigma Baru. Bandung : PT.Remaja Rosdakarya

Aunurrahman. (2013). Belajar dan Pembelajaran.Bandung : Alfabeta

Budiningsih, A. (2005). Belajar dan Pembelajaran. Jakarta : Rineka Cipta

Dimyati dan Mudjiono. (2009). Belajar dan Pembelajaran. Jakarta : Rineka Cipta

Djamarah, SB (2000). Psikologi Belajar. Jakarta : Rineka Cipta

Husamah. (2014). Pembelajaran Bauran (Blended Learning). Jakarta : Prestasi Pustakarya

Isjoni dan L.N Firdaus (eds). (2008). Pembelajaran Terkini Perpaduan Indonesia-Malaysia.Yogyakarta : Pustaka Belajar

Muawanah. (2008). Konsep Dasar Akuntansi dan Pelaporan Keuangan Jilid 2 untuk SMK. Jakarta : Direktorat Pembinaan Sekolah Menengah Kejuruan

Riyanto, Y. (2010). Paradigma Baru Pembelajaran: Sebagai Referensi Bagi Guru/ Pendidik Dalam Implementasi Pembelajaran yang Efektif dan Berkualitas. Jakarta : Kencana Prenada Media Grup

Sagala, S. (2010). Konsep dan Makna Pembelajaran. Bandung : Alfabeta

Slameto.(2010). Belajar Dan FaktorFaktor Yang Mempengaruhinya. Jakarta : PT. Rineka Cipta.
Sudjana. (2000). Statistika Untuk Ekonomi dan Niaga Jilid I. Bandung: Tarsito

(2004). Statistika Untuk Ekonomi dan Niaga Jilid II.Bandung : Tarsito

(2010). Evaluasi Proses Dan Hasil Pembelajaran.Jakarta : Bumi Aksara

Sugiyono. (2005).Memahami Penelitian Kualitatif. Bandung: Alfabeta

(2012). Metode Penelitian Administrasi.Bandung : Alfabeta Sukardi. (2010). Evaluasi Pendidikan : Prinsip dan Operasionalnya. Jakarta : Bumi AksaraSuprayekti. (2003). Interaksi Belajar Mengajar. Jakarta : Direktorat Tenaga Kependidikan, Dikdasmen, Depdiknas. Depdiknas.

Syah, M. (2011). Psikologi Pendidikan Suatu Pendekatan Baru. Bandung: Remaja Rosdakarya.

(2006). Psikologi

Belajar. Jakarta: Raja Grafindo Persada

Uno, H.B dan Lamatenggo.N. (2010). Teknologi Komunikasi dan Informasi Pembelajaran. Jakarta : Bumi Aksara

Jurnal :

M. Yusuf. T. (2011).Blended Learning : Model Pembelajaran KombinasiE-Learning Dalam Pendidikan Jarak Jauh. Vol. 14 No 2 p.232.242

Yusuf. (2011). Mengenal Blended Learning. Lentera Pendidikan, VOL. 14 No. 2

Akkoyunlu, B., \& Soylu, M. Y. (2008). A Study of Student's Perceptions in a Blended Learning Environment Based on DifferentLearning Styles. 
Educational Technology \& Society, 11 (1), 183-193

(2008). Development of a scale on learners' views on blended learning and its implementation process. Internet and Higher Education., 11 (2008), 26-32

Melton,B, Graf,H and Chopak.J. (2009). Achievement and Satisfaction in Blended Learningversus Traditional General Health Course Designs. Vol.3 no.1

Chen,C and Jones,K. (2007). Blended Learning vs. Traditional Classroom Settings: Assessing Effectiveness and Student Perceptions in an MBA Accounting Course. The Journal of Educators Online. Volume 4, Number 1.

\section{Dokumen :}

Sukarno. Blended Learning Sebuah Alternatif Model Pembelajaran Mahasiswa Program Sarjana (S-1) Kependidikan Bagi Guru Dalam
Jabatan. Program PGSD FKIP Universitas Sebelas Maret Surakarta Undang-undang No.20 Tahun 2003 Tentang Sistem Pendidikan Nasional Program Studi Pendidikan Akuntansi. (2013). Pedoman Operasional Penulisan Skripsi. Bandung : Universitas Pendidikan Indonesia

Tim Akuntansi SMK. Modul Akuntansi Mengelola Buku Jurnal. (2007). Jakarta : PT.Galaxy Puspa Mega

Seomantri, Hendi. Dasar-Dasar Akuntansi SMK Kelompok Bisnis dan Manajemen. Bandung : Armico

Internet :

Sidiknas. (2014). Struktur Kurikulum 2013. [Online]. Tersedia : http://www.kemdiknas.go.id/kemdikb ud/uii-publik-kurikulum-2013-4

Name. (2010). Tabel Statistika. [Online]. Tersedia http://junaidichaniago.wordpress.co $\underline{\mathrm{m}}$ 